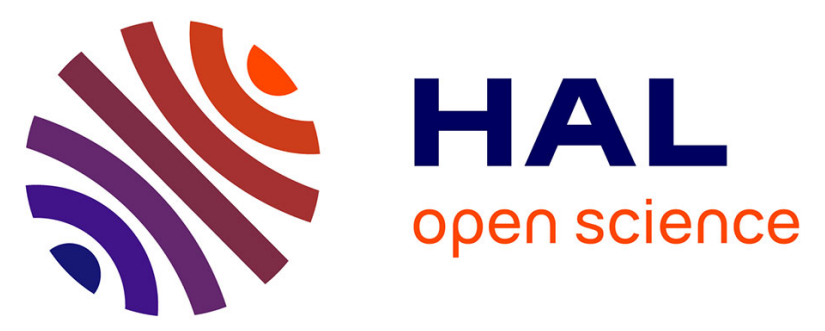

\title{
Tibetan Plateau made central Asian drylands move northward, concentrate in narrow latitudinal bands, and increase in intensity during the Cenozoic
}

\author{
Ran Zhang, Zhongshi Zhang, Dabang Jiang, Gilles Ramstein, Guillaume \\ Dupont-Nivet, Xiangyu Li
}

\section{To cite this version:}

Ran Zhang, Zhongshi Zhang, Dabang Jiang, Gilles Ramstein, Guillaume Dupont-Nivet, et al.. Tibetan Plateau made central Asian drylands move northward, concentrate in narrow latitudinal bands, and increase in intensity during the Cenozoic. Geophysical Research Letters, 2022, 49 (3), pp.e2021GL093718. 10.1029/2021gl093718 . insu-03542140v2

HAL Id: insu-03542140

https://hal-insu.archives-ouvertes.fr/insu-03542140v2

Submitted on 2 Feb 2022

HAL is a multi-disciplinary open access archive for the deposit and dissemination of scientific research documents, whether they are published or not. The documents may come from teaching and research institutions in France or abroad, or from public or private research centers.
L'archive ouverte pluridisciplinaire HAL, est destinée au dépôt et à la diffusion de documents scientifiques de niveau recherche, publiés ou non, émanant des établissements d'enseignement et de recherche français ou étrangers, des laboratoires publics ou privés. 


\section{Geophysical Research Letters}

\author{
RESEARCH LETTER \\ 10.1029/2021GL093718 \\ Key Points: \\ - Changed land-sea distribution and \\ atmospheric $\mathrm{CO}_{2}$ concentration \\ promote aridification of drylands bu \\ only slightly affect their latitudinal \\ position \\ - The growth of the TP makes central \\ Asian drylands move northward, \\ concentrate in narrow latitudinal \\ bands, and increase in intensity \\ - The uplift of the main and northern \\ TP by the early Miocene likely forced \\ the drylands to form in central Asia \\ north of $\sim 40^{\circ} \mathrm{N}$
}

Supporting Information:

Supporting Information may be found in the online version of this article.

Correspondence to:

R. Zhang,

zhangran@mail.iap.ac.cn

Citation:

Zhang, R., Zhang, Z., Jiang, D. Ramstein, G., Dupont-Nivet, G., \& Li, X. (2022). Tibetan Plateau made central Asian drylands move northward, concentrate in narrow latitudinal bands, and increase in intensity during the Cenozoic. Geophysical Research Letters, 49, e2021GL093718. https://doi. org/10.1029/2021GL093718

Received 5 APR 2021

Accepted 18 JAN 2022
(C) 2022. American Geophysical Union. All Rights Reserved.

\section{Tibetan Plateau Made Central Asian Drylands Move Northward, Concentrate in Narrow Latitudinal Bands, and Increase in Intensity During the Cenozoic}

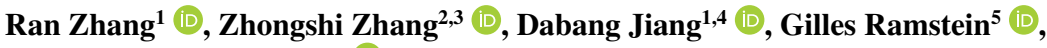 \\ Guillaume Dupont-Nivet ${ }^{6}{ }^{(D}$, and ${\mathrm{Xiangyu} \mathrm{Li}^{2}}^{2}$ \\ ${ }^{1}$ Institute of Atmospheric Physics, Chinese Academy of Sciences, Beijing, China, ${ }^{2}$ Department of Atmospheric Science, \\ School of Environmental Studies, China University of Geosciences, Wuhan, China, ${ }^{3}$ Uni Research Climate, Bjerknes Center \\ for Climate Research, Bergen, Norway, ${ }^{4}$ National Institute of Natural Hazards, Ministry of Emergency Management of China, \\ Beijing, China, ${ }^{5}$ Laboratoire des Sciences du Climat et de l'Environnement/IPSL, CEA-CNRS-UVSQ, Gif-sur-Yvette Cedex, \\ France, ${ }^{6}$ Université de Rennes, CNRS, Rennes, France
}

\begin{abstract}
The evolution of central Asian drylands during the Cenozoic is a hot topic in paleoclimate research, but the underlying mechanism remains unclear. Here, we investigate this topic with climate modeling based on six key geological periods. Our results indicate that central Asian drylands have existed since the early Eocene, after which they move northward and become narrower. Although changed land-sea distribution and decreased atmospheric $\mathrm{CO}_{2}$ concentration promote the aridification of drylands, they only slightly affect the latitudinal position of drylands. By comparison, the growth of Asian high-topography areas, especially the Tibetan Plateau (TP), makes central Asian drylands move northward, concentrate in narrow latitudinal bands, and increase in intensity. Good model-data qualitative agreement is obtained for stepwise aridification in midlatitude inland Asia north of $\sim 40^{\circ} \mathrm{N}$, and the uplifted main and northern TP by the early Miocene likely forced drylands to form in this region.
\end{abstract}

Plain Language Summary Drylands in central Asia (approximately $40-50^{\circ} \mathrm{N}, 70-105^{\circ} \mathrm{E}$ ) have a very long and complex evolutionary history during the Cenozoic. Previous modeling studies have mainly considered specific geological period and factors; however, few attempts have been made to quantify the role of different factors on the characteristics of central Asian drylands through geologic time and to investigate the changes in these characteristics under different evolved scenarios of the Tibetan Plateau (TP). The mechanism behind the changes in position, range, and intensity of central Asian drylands during the Cenozoic remains unclear. In this study, we ran 44 experiments to investigate the respective roles of Asian topography, land-sea distribution, atmospheric $\mathrm{CO}_{2}$ concentration and Antarctic ice sheet on central Asian drylands. Our model results indicate that central Asian drylands have existed since the early Eocene. The Paratethys Sea retreat and the atmospheric $\mathrm{CO}_{2}$ concentration reduction promote the aridification of drylands, but they only slightly affect the latitudinal position of drylands. With the growth of Asian high-topography areas, especially the TP, central Asian drylands move northward, concentrate in narrow latitudinal bands, and increase in intensity.

\section{Introduction}

Today, most global drylands are located between $\sim 20^{\circ}$ and $40^{\circ} \mathrm{N}$, whereas Asian inland drylands, one of the most climate sensitive and vulnerable regions in the world (Lioubimtseva \& Henebry, 2009), span from northwestern China to middle Asia at higher latitudes. In particular, central Asia (approximately $40-50^{\circ} \mathrm{N}, 70-105^{\circ} \mathrm{E}$ ) hosts steppe-desert biomes and is characterized by summer-dominated low precipitation (Barbolini et al., 2020). Drylands in central Asia have a very long and complex evolutionary history during the Cenozoic (Caves \& Chamberlain, 2018; Lu et al., 2019), accompanied by ancient biomes characterized by a predominance of shrubs, forest, and ferns rather than herbs (Barbolini et al., 2020; Sun \& Wang, 2005). They can be traced back to the early Eocene (Li et al., 2018; Licht et al., 2016) and become more pronounced throughout the Eocene-Oligocene transition (Dupont-Nivet et al., 2007), late Oligocene (Zheng et al., 2015), and early Miocene (Sun \& Wang, 2005; Zhang et al., 2015). More humid conditions prevail during the Middle Miocene Climatic Optimum (MMCO; Miao et al., 2012), while these drylands have undergone stepwise intensified aridification since the late Miocene (Fang et al., 2015). 
Previous studies have demonstrated that changes in land-sea distributions, Asian topography, and global cooling can affect central Asian drylands. The retreat of the Paratethys Sea strengthens Asian inland aridity (Meijer et al., 2019; Ramstein et al., 1997) by reducing the water vapor supply to the Asian interior. The uplift of Asian high mountains, particularly the Tibetan Plateau (TP), intensifies Asian inland aridity through the intensification of descending air related to orographic rain shadows (Zhang et al., 2012; Zoura et al., 2019). Cenozoic global cooling enhances Asian inland aridity by weakening regional hydrological cycles (Li et al., 2018; Lu et al., 2019). Previous paleoclimate modeling studies have mainly investigated central Asian drylands in response to those factors for specific time periods (Botsyun et al., 2019; Farnsworth et al., 2019; Liu et al., 2019; Tardif et al., 2020; Zoura et al., 2019). However, few attempts have been made to quantify the role of different factors on central Asian drylands through geologic time and to check the changes in central Asian drylands under different evolved scenarios of the TP (Deng et al., 2019; Spicer et al., 2020; Su et al., 2019; Wang et al., 2014) because of the debated uplift history of the TP. Thus, the mechanism behind the changes in position, range, and intensity of central Asian drylands during the Cenozoic remains unclear, and a comparison among climate effects from various factors with several evolved scenarios of the TP is required.

Here, we carry out a set of modeling experiments to investigate the evolution of central Asian drylands during the Cenozoic. We use the low-resolution Norwegian Earth System Model (NorESM-L; Zhang et al., 2014) and Community Atmosphere Model version 4 (CAM4; Neale et al., 2013) based on six key geological periods (early Eocene, late Eocene, early Oligocene, early Miocene, late Miocene, and late Pliocene). We carry out 14 experiments with NorESM-L, together with 30 experiments with CAM4, to distinguish the effects arising from the TP uplift, the Paratethys Sea retreat, the atmospheric $\mathrm{CO}_{2}$ concentration reduction and the Antarctic ice sheet expansion on the position, range, and intensity of central Asian drylands during the Cenozoic. In addition, we also consider several scenarios of the TP height according to asynchronous uplift across different regions of the TP (Tapponnier et al., 2001; Wang et al., 2014) in our sensitivity experiments. We use the aridity index (AI), recommended by the Food and Agriculture Organization (FAO) and widely used (Fu \& Feng, 2014), to show the simulated Asian drylands.

\section{Methods}

\subsection{Models and Boundary Conditions}

NorESM-L and CAM4 are used here. NorESM-L was developed at the Bjerknes Center for Climate Research. CAM4, the atmospheric component, has a horizontal resolution of $\sim 3.75^{\circ} \times 3.75^{\circ}$ (Spectral T31) with 26 vertical levels. The land component (Community Land Model version 4) adopts the same horizontal resolution as CAM4. The ocean component (Miami Isopycnic Coordinate Ocean Model) has a nominal $3^{\circ}$ horizontal resolution and 32 vertical levels. The sea ice component is the Los Alamos Sea Ice Model version 4. NorESM-L has been demonstrated to be able to capture the present-day climate and paleoclimates (Bentsen et al., 2013; Zhang et al., 2014). Moreover, CAM4, with a horizontal resolution of $\sim 1^{\circ}$ (configured by $\sim 0.9^{\circ}$ in latitude and $1.25^{\circ}$ in longitude) and 26 vertical layers, has also been used for atmospheric-only experiments. At this resolution, CAM4 uses a finite-volume dynamical core and reasonably reproduces the large-scale pattern of the current Asian climate (Neale et al., 2013). These CAM4 experiments run with fixed vegetation distribution and phenology and no carbon and nitrogen cycle is considered.

The paleogeographic configurations for the early Eocene ( $\sim 50 \mathrm{Ma})$, late Eocene ( 40 Ma), early Oligocene ( $\sim 30 \mathrm{Ma})$, early Miocene ( 20 Ma), and late Miocene $(\sim 10 \mathrm{Ma})$ are based on reconstructed paleogeographic maps (Scotese, 2001) and further digitized by Zhang et al. (2014). For the late Pliocene ( 3 Ma), we use the reconstructed topography from PRISM3D (Dowsett et al., 2010) with a modern land-sea mask. For the greenhouse gases, we set the atmospheric $\mathrm{CO}_{2}$ concentration to $1120,1050,700,420,350$, and 405 ppmv for these six periods in one group and keep these values at 560 ppmv for first five periods in another group, in accordance with a previous synthesis (Beerling \& Royer, 2011). Other greenhouse gases (e.g., $\mathrm{CH}_{4}$ and $\mathrm{N}_{2} \mathrm{O}$ ) are fixed at the preindustrial levels (year 1850). Given the scarcity of proxies for vegetation during the Cenozoic, we adopt the same idealized land cover for first five periods and the PRISM3D reconstructions for the late Pliocene. In addition, no ice sheets are included, except for those set for the late Pliocene and Antarctic ice sheet sensitivity experiments. 


\subsection{Experimental Design and AI}

Due to the long simulation time required by using a high-resolution fully coupled model, we use simulated climatologically averaged 12 months sea surface temperatures (SSTs) from NorESM-L experiments to force CAM4 experiments (Tables S1 and S2 in Supporting Information S1). To keep consistent of the boundary conditions between experiments with two models, we use the paleogeographic conditions from NorESM-L experiments in CAM4 experiments. The elevation conditions in CAM4 experiments are the same as that in NorESM-L experiments except that in Asia. Due to the debated evolution history of Asian topography and to emphasize the climate effects of the growth of the TP, we keep and modify the topography in and around the TP and remove other Asian topography in CAM4 experiments. These NorESM-L experiments are generally run for more than 2,000 model years (Table S1 in Supporting Information S1). Each CAM4 experiment is run for 25 model years. These CAM4 experiments reach a quasi-equilibrium state in their first five model years; therefore, the computed climatological means of the last 20 model years are analyzed below.

We first simulate the climate of the early Eocene, late Eocene, early Oligocene, early Miocene, and late Miocene with and without changing the atmospheric $\mathrm{CO}_{2}$ concentration (Table S2 in Supporting Information S1). Through comparison, we can measure the climate effect of atmospheric $\mathrm{CO}_{2}$ concentrations. Moreover, to investigate the climate effect of an Antarctic ice sheet on central Asian aridity, we conduct two sensitivity experiments under early and late Miocene paleogeography (Table S2 in Supporting Information S1). The Antarctic ice sheet and accompanying topography used in these experiments are derived from late Pliocene conditions (Haywood et al., 2011), which is reasonable compared with the corresponding reconstruction (Paxman et al., 2019) and previous modeling studies (Goldner et al., 2015).

In the above simulations, the TP gradually uplifted and moved northward. To further constrain the effect of changes in Asian topography, we consider asynchronous uplift across different regions of the TP (Tapponnier et al., 2001; Wang et al., 2014). Moreover, we further investigate the effects of the uplifting main TP from the early Oligocene to the early Miocene by considering several scenarios of the main TP height (Deng et al., 2019; Spicer et al., 2020; Su et al., 2019; Wang et al., 2014). In particular, the main TP may reach approximately 2,000 $\mathrm{m}$ (Deng et al., 2019) or more than 4,000 $\mathrm{m}$ with the low northern part (Wang et al., 2014) and further the deep central valley (Fang et al., 2020; Spicer et al., 2020; Su et al., 2019) in the early Oligocene. Meanwhile, the latitudinal position of the main TP is possibly $\sim 3^{\circ}$ further south in the early Oligocene, while the position is near the present state by the early Miocene (Lippert et al., 2014).

To isolate the effects of Asian topography, we use a flat Asian topography (maximum elevation of $300 \mathrm{~m}$ ) in the regions of $0^{\circ}-70^{\circ} \mathrm{N}$ and $50^{\circ}-140^{\circ} \mathrm{E}$ (Table S2 in Supporting Information S1). Moreover, according to the Asian topography evolution scenarios mentioned above, we conduct additional sensitivity experiments under early Miocene boundary conditions (Table S2 in Supporting Information S1). In these experiments, the topography is changed but other boundary conditions are unchanged, such as vegetation, soil color, and constitution.

$\mathrm{AI}$ is defined as the ratio of the annual precipitation to the annual potential evapotranspiration (PET). We apply the Penman-Monteith algorithm to estimate PET (Allen et al., 1998; Fu \& Feng, 2014), in which the effects of surface air temperature, available energy, wind speed, and relative humidity are taken into account. Here, dry regions are defined as those for which the AI is less than 0.65 and are further classified into dry-subhumid $(0.5 \leq \mathrm{AI}<0.65)$, semiarid $(0.2 \leq \mathrm{AI}<0.5)$, arid $(0.05 \leq \mathrm{AI}<0.2)$, and hyperarid $(\mathrm{AI}<0.05)$ regions, and wet regions are defined as those for which the AI is greater than 0.65 . The algorithm for PET is detailed as follows:

$$
\mathrm{PET}=\frac{0.408 \Delta\left(R_{n}-G\right)+\gamma \frac{900}{T+273} U_{2}\left(e_{s}-e_{a}\right)}{\Delta+\gamma\left(1+0.34 U_{2}\right)}
$$

where PET is the potential evapotranspiration $\left(\mathrm{mm} \mathrm{day}^{-1}\right), R_{n}$ is the net radiation at the land surface $\left(\mathrm{MJ} \mathrm{m}^{-2} \mathrm{day}^{-1}\right)$, $G$ is the soil heat flux density $\left(\mathrm{MJ} \mathrm{m}^{-2}\right.$ day $\left.^{-1}\right), \Delta$ is the slope vapor pressure curve $\left(\mathrm{kPa}^{\circ} \mathrm{C}^{-1}\right), \gamma$ is the psychrometric constant $\left(\mathrm{kPa}^{\circ} \mathrm{C}^{-1}\right), T$ is the mean daily air temperature at $2 \mathrm{~m}$ height $\left({ }^{\circ} \mathrm{C}\right), U_{2}$ is the wind speed at $2 \mathrm{~m}$ height $\left(\mathrm{m} \mathrm{s}^{-1}\right), e_{s}$ is the saturation vapor pressure $(\mathrm{kPa})$, and $e_{a}$ is the actual vapor pressure $(\mathrm{kPa})$.

The model could reasonably simulate the extent and aridity of the Asian dryland based on the evaluation with long-term mean observations and reanalysis data for the period 1981-2010 (Kanamitsu et al., 2002; Schneider et al., 2011). In the observations (Figure S1 in Supporting Information S1), drylands are widely distributed in 

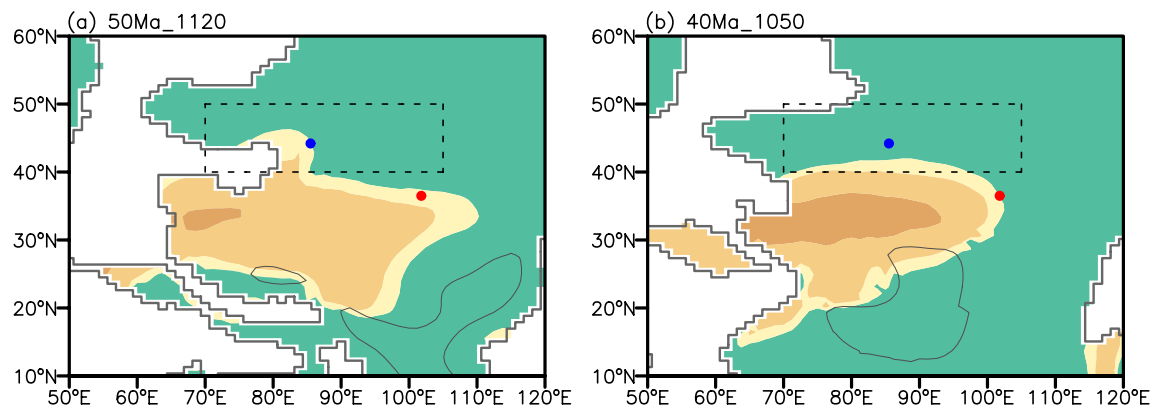

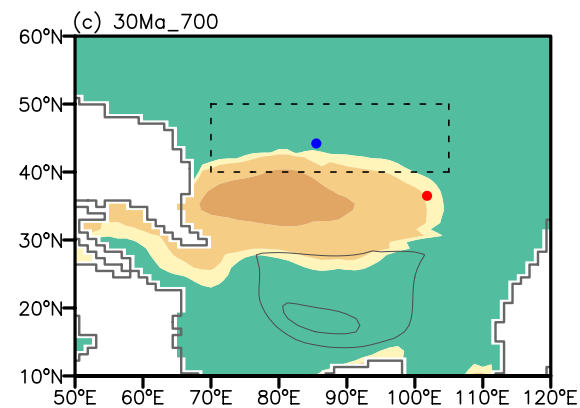

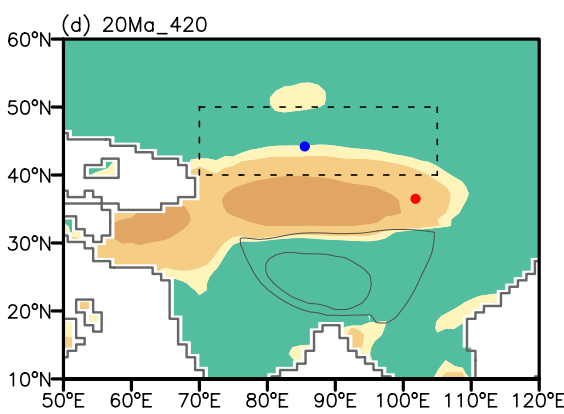
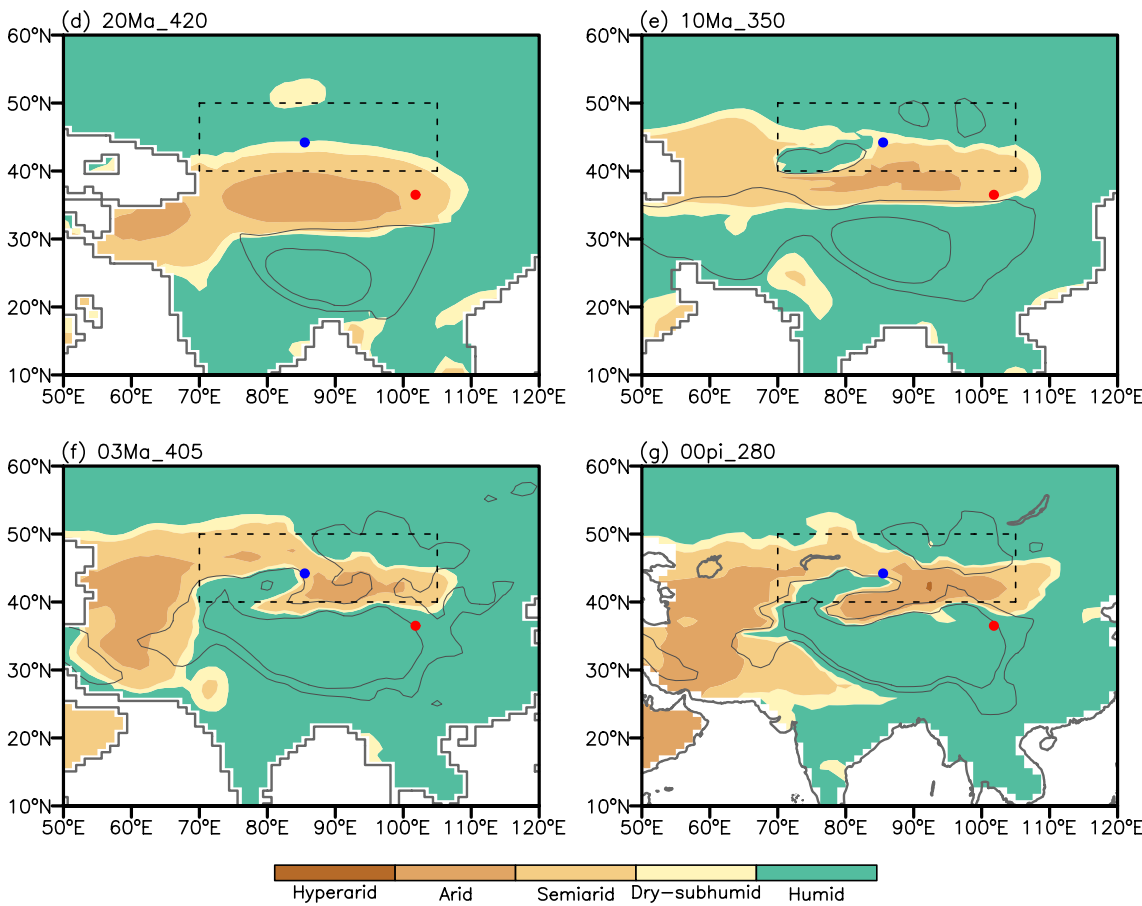

Figure 1. The simulated distribution of the climate types (shaded) measured by the aridity index (AI) in experiments with changed Asian topography and atmospheric $\mathrm{CO}_{2}$ concentration. Topography levels equal to 1,500 and $3,000 \mathrm{~m}$ are highlighted with gray contours, and the dashed black box represents central Asia $\left(40^{\circ}-50^{\circ} \mathrm{N}\right.$, $70^{\circ}-105^{\circ} \mathrm{E}$ ), which also applies to the following plots. The blue and red circles represent the modern positions of northern Tian Shan (Tang et al., 2011) and Xining basin (Bosboom et al., 2014; Hoorn et al., 2012), respectively.

central and southwestern Asia. The observed distribution matches with varying types of surface vegetation, that is, barren, open shrublands, savannas, and grasslands (Fu \& Feng, 2014). Our preindustrial experiment reasonably simulates the observed locations of Asian drylands, although it underestimates the dryland extent over Northwest China.

\section{Results}

\subsection{Modeled Central Asian Drylands During the Cenozoic}

In our simulations, central Asian drylands have existed since the early Eocene and are mainly located between $\sim 20^{\circ} \mathrm{N}$ and $\sim 40^{\circ} \mathrm{N}$ during the early Cenozoic (Figure 1). These drylands are caused by both less annual precipitation and more annual PET in the central and western parts of the continent (Figures S2 and S3 in Supporting Information S1). Due to strengthened regional hydrological cycles from a warmer climate and a shorter distance from the proto-Paratethys Sea to inland Asia, water vapor transport by the westerlies from the proto-Paratethys Sea into inland Asia is strong in the early Cenozoic. However, the descending air masses associated with the Hadley high-pressure cell limit precipitation (Zhang et al., 2012), thus resulting in Asian inland drylands between $\sim 20^{\circ} \mathrm{N}$ and $\sim 40^{\circ} \mathrm{N}$ (Figures 2, 3 and S4 in Supporting Information S1). 

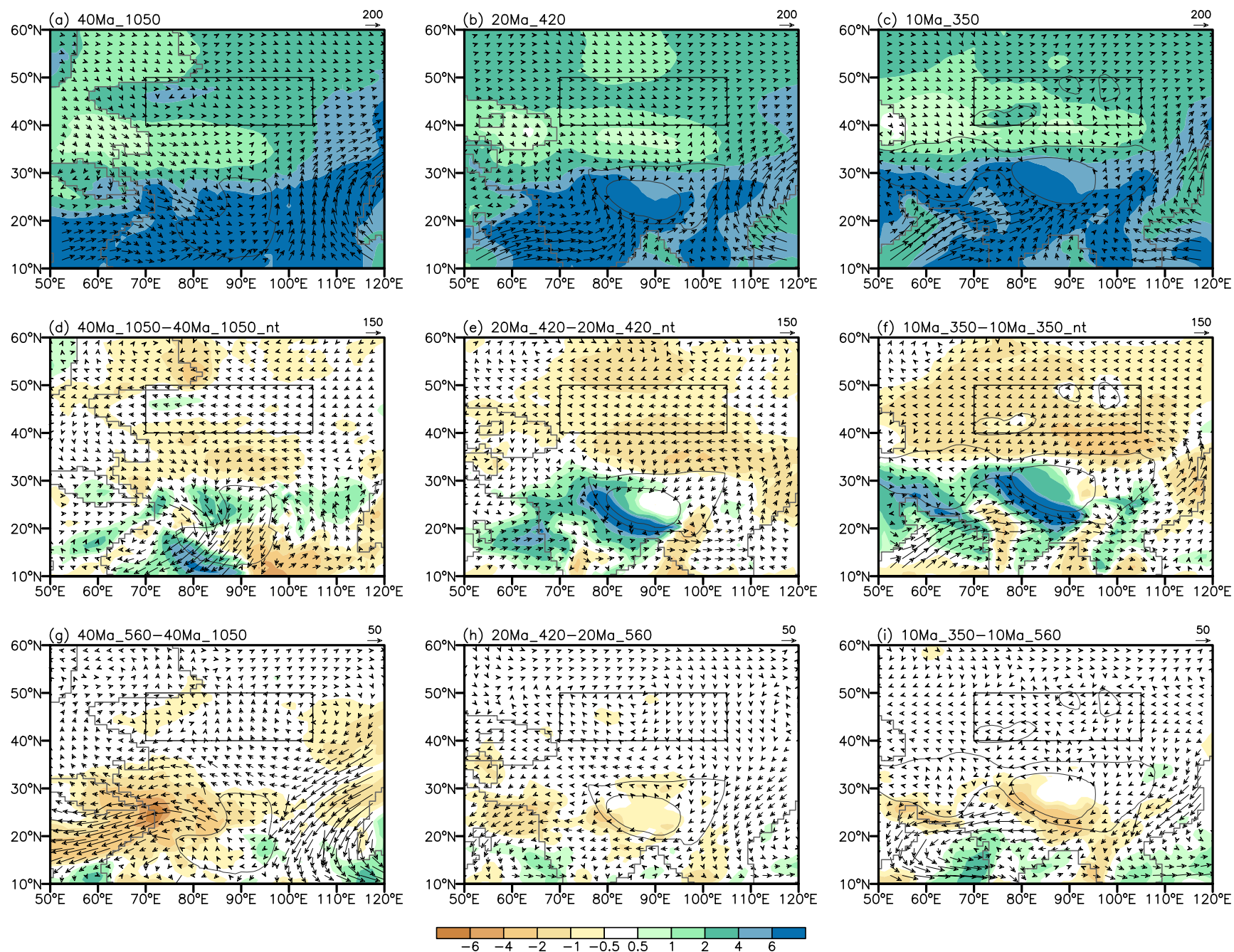

Figure 2. Differences in simulated summer (May to September) precipitation (shaded; units: $\mathrm{mm} \mathrm{day}^{-1}$ ) and water vapor transport integrated from the surface to $700 \mathrm{hPa}$ (vector; units: $\mathrm{kg} \mathrm{m}^{-1} \mathrm{~s}^{-1}$ ) due to the uplifted Asian topography (d-f) and decreased atmospheric $\mathrm{CO}_{2}$ concentration (g-i) under late Eocene, early Miocene and late Miocene boundary conditions.

Central Asian drylands start moving northward into north of $\sim 40^{\circ} \mathrm{N}$ since about the early Miocene. From the Eocene to Oligocene, simulated central Asian drylands are mainly located between $\sim 20^{\circ} \mathrm{N}$ and $\sim 40^{\circ} \mathrm{N}$ (Figures $1 \mathrm{~b}$ and 1c). Since about the early Miocene, central Asian drylands move northward gradually into north of $\sim 40^{\circ} \mathrm{N}$ and become narrower (Figures 1d-1f). The intensified aridity in the higher latitudes in central Asia is essentially caused by the decreased annual precipitation, since the PET does not increase in the region (Figures S2 and S3 in Supporting Information S1). In central Asia, most of the changed annual precipitation between experiments is caused by that in summer (May to September; Figure S5 and Table S3 in Supporting Information S1) due to changes in water vapor transport (Figures 2 and S5 in Supporting Information S1) and vertical motion (Figures 3 and S6 in Supporting Information S1).

\subsection{Impact of Different Factors on Central Asian Drylands}

As demonstrated in our sensitivity experiments, simulated Asian drylands are always located between $\sim 20^{\circ} \mathrm{N}$ and $\sim 40^{\circ} \mathrm{N}$, when the Asian topography is flat. Few drylands are located in central Asia north of $\sim 40^{\circ} \mathrm{N}$, regardless of the land-sea distribution conditions (Figure S7 in Supporting Information S1). Simulated drylands between $\sim 20^{\circ} \mathrm{N}$ and $\sim 40^{\circ} \mathrm{N}$ are caused by low annual precipitation and high PET (Figures S8 and S9 in Supporting Information S1). Moreover, when the Asian topography is flat, the shrinkage of the Paratethys Sea and the drop in atmospheric $\mathrm{CO}_{2}$ concentration enlarge drylands but do not squeeze drylands into higher latitudes (Figure S7 in Supporting Information S1). 

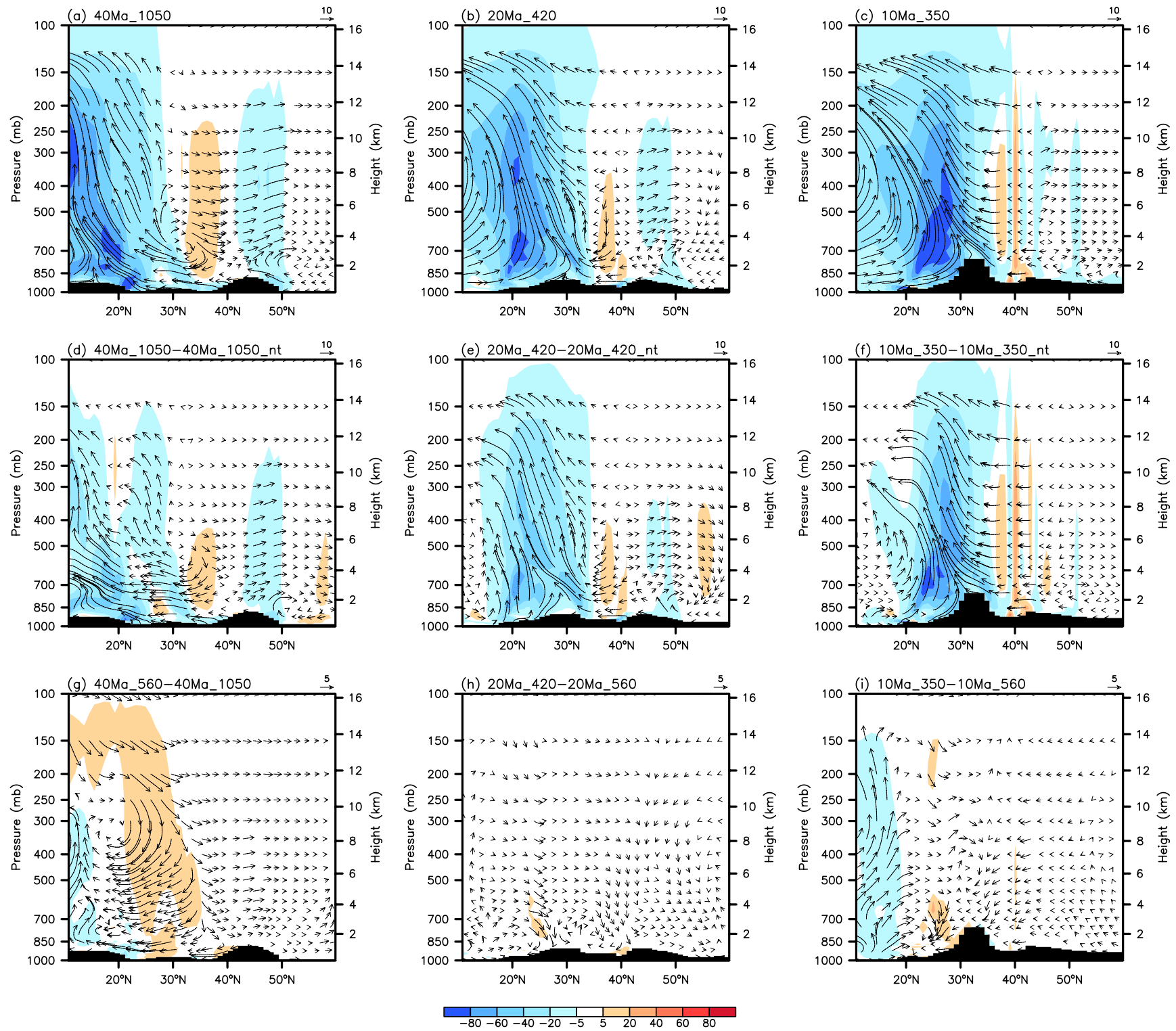

Figure 3. Differences in simulated summer (May to September) meridionally averaged $\left(70^{\circ}-90^{\circ} \mathrm{E}\right)$ vertical velocity (shaded, units: $\mathrm{hPa}$ day $\left.{ }^{-1}\right)$ and wind circulation due to the uplifted Asian topography (d-f) and decreased atmospheric $\mathrm{CO}_{2}$ concentration ( $\mathrm{g}-\mathrm{i}$ ) under late Eocene, early Miocene, and late Miocene boundary conditions. Upward motion is negative and downward motion is positive. Vectors are vertical velocity (units: $\mathrm{hPa} \mathrm{day}^{-1}$ ) versus meridional wind (units: $\mathrm{m} \mathrm{s}^{-1}$ ). The black shaded regions denote the topography.

The retreat of the Paratethys Sea increases the distance of eastward water vapor transport to central Asia, thus reducing the water vapor supply into central Asia (Figure S5 in Supporting Information S1). Therefore, the shrinkage significantly decreases inland precipitation (in particular in winter) and enhances seasonality in precipitation and regional aridity in central Asia. In particularly, the distinct retreat of the Paratethys Sea occurs from the Tarim Basin through the early Eocene to late Eocene/early Oligocene and from the Pamir to the Caspian basin during the early to late Miocene in our simulations. However, it does not play a dominant role in the northward shift of central Asian drylands when compared to the impact of Asian topography.

The decrease in atmospheric $\mathrm{CO}_{2}$ concentration can reduce annual precipitation in central Asia. The decreased annual precipitation (Figure S10 and Table S3 in Supporting Information S1) derives mainly from summer due to the weakened water vapor supply from the cooled atmosphere (Figure 2) and intensified regional descending motion (Figure 3). Although the decreased atmospheric $\mathrm{CO}_{2}$ concentration can enhance aridity in central Asia, it only slightly changes the latitudinal position of drylands (Figure 1 versus Figure S11 in Supporting Information S1). 

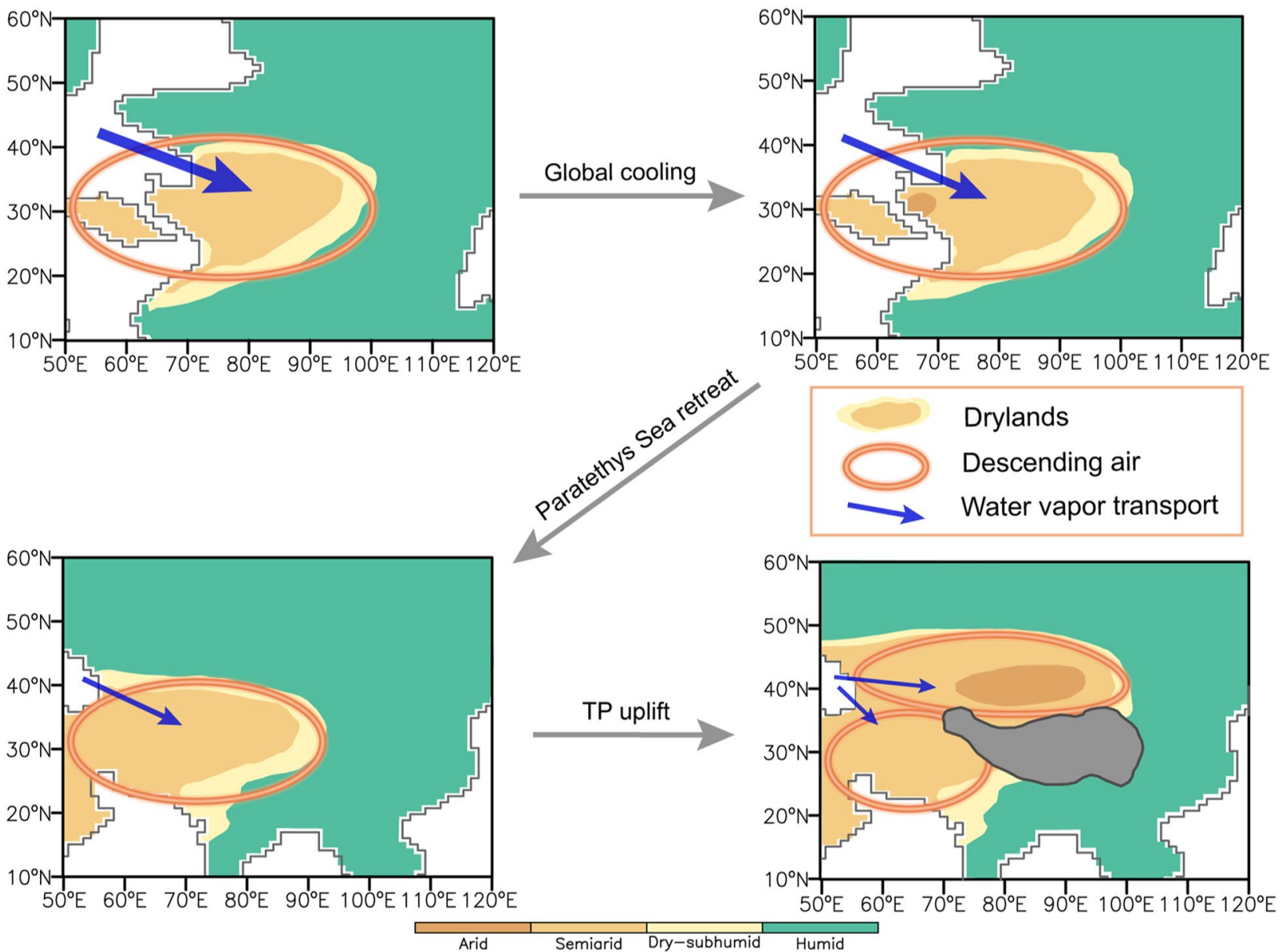

Figure 4. Cartoon illustrating the impacts from global cooling, Paratethys Sea retreat and Tibetan Plateau (TP) uplift on Asian drylands. The decreased atmospheric $\mathrm{CO}_{2}$ concentration and the retreated Paratethys Sea weaken the water vapor transport and promote aridification in inland Asia, but they only slightly change the latitudinal position of dryland. The uplift of the TP makes Asian drylands move northward, concentrate in narrow latitudinal bands and increase in intensity mainly through intensification of descending air in the north of the TP. Note. The water vapor transport from the Indian and Pacific Oceans is not shown.

For example, when the atmospheric $\mathrm{CO}_{2}$ concentration is reduced from 1,120 to $560 \mathrm{ppmv}$ in the Eocene experiments, simulated drylands remain between $\sim 20^{\circ} \mathrm{N}$ and $\sim 40^{\circ} \mathrm{N}$ but with higher aridity (Figure 1 versus Figure S11 in Supporting Information S1). In addition to the atmospheric $\mathrm{CO}_{2}$ concentration, we analyze the effects of the expanded Antarctic ice sheet on central Asian drylands under the early and late Miocene boundary conditions, and their effects on the distribution of central Asian drylands are weak (Figure S12 in Supporting Information S1).

Therefore, our simulations demonstrate that the Asian topography plays a dominant role in squeezing central Asian drylands into the higher midlatitudes between $\sim 40^{\circ} \mathrm{N}$ and $\sim 50^{\circ} \mathrm{N}$ by reducing the water vapor transport from the ocean and intensifying the regional descending motion (Figures 2 and 3). The uplift of Asian topography also modulates the responses of central Asian drylands to changes in land-sea distribution and atmospheric $\mathrm{CO}_{2}$ concentration. This is because the existing Asian topography largely affects climatological water vapor transport and vertical motion through the strengthened land-sea thermal contrast and pressure gradient, which further affect the responses of central Asian drylands to other factors (Figures 2 and 3).

We conduct more sensitivity experiments to investigate the impact of asynchronous uplift across different regions of Asian topography (Figure S13 in Supporting Information S1). These experiments demonstrate that the northward growth of the TP plays a more essential role in constraining Asian inland drylands at higher latitudes than Mongolian Plateau and Tian shan, and the uplift of the northern TP (at its current latitude position) is more important than that of other parts of the TP in constraining drylands in central Asia (Figures 4 and S13 in Supporting Information S1). The uplift of Mongolian Plateau and Tian shan affects only the spatiotemporal 
distribution of precipitation in inland Asia and slightly modifies the latitudinal position of drylands in central Asia (Sha et al., 2018; Wang et al., 2020). The relatively low height (approximately 2,000 m) of the main TP with a southern position can maintain a wet environment in central Asia north of $\sim 40^{\circ} \mathrm{N}$ (Figure S13 in Supporting Information S1). Along with the uplift of the main TP (from $\sim 2,000$ to $\sim 4,000 \mathrm{~m}$ ) and its northward motion, the growth of the TP can expand drylands in central Asia north of $\sim 40^{\circ} \mathrm{N}$ (Figure S13 in Supporting Information S1). In addition, with the uplift of only the main TP, simulated central Asian drylands are still less abundant than those in the late Pliocene, indicating the further expansion of these drylands forced by the uplift of the northern TP.

\section{Discussion}

\subsection{Uncertainties in Simulations}

It is not surprising that our current simulations do not illustrate the zonal arid belt in China in the Paleogene simulations (Guo et al., 2008; Sun \& Wang, 2005). During the Paleogene, both the simulations and geological data demonstrate that the climate is wetter in the eastern part than in the western part of China (Farnsworth et al., 2019; Quan et al., 2014; Tardif et al., 2020). For example, in the Eocene pollen assemblage, although Ephedripites (arid plant) exists at all sites from the western to eastern parts of China, the percentage of Ephedripites remains lower in the eastern than in the western parts of China (Sun \& Wang, 2005). However, the wetter climate in the eastern part of China does not indicate the existence of a modern-like monsoon climate during the Paleogene, as demonstrated in earlier simulations (Tardif et al., 2020; Zhang et al., 2018). The simulated zonal-like arid climate pattern likely depends on the topography boundary conditions (Farnsworth et al., 2019).

Despite the potential modeling uncertainties, the results of the 30 CAM4 experiments show that the uplift of Asian high-topography areas, especially the TP, is the key forcing that is driving central Asian drylands into higher latitudes. Although changes in land-sea distributions and drops in atmospheric $\mathrm{CO}_{2}$ concentrations can enhance Asian inland aridity, they are not the key forcings that are driving central Asian drylands to latitudes higher than $\sim 40^{\circ} \mathrm{N}$. However, the uplift history of the TP remains hotly debated; recent studies suggest that the different regions in the TP rise asynchronously. Despite the large uncertainties in constraining the elevation and extent of the TP during the Cenozoic, our sensitivity experiments demonstrate that the uplift of the northern TP is more important than that of other parts of the TP in constraining Asian drylands to the higher latitudes (Figure S13 in Supporting Information S1). The main TP, including the Lhasa and Qiangtang areas, likely uplifted before the Neogene (Royden et al., 2008; Wang et al., 2014), while the marginal TP and surrounding regions, including the Himalaya and Qilian Mountain, uplifted later (Ding et al., 2017; Li et al., 2014; Tapponnier et al., 2001). The uplift of the main TP from the early Oligocene to the early Miocene possibly expanded drylands in central Asia north of $\sim 40^{\circ} \mathrm{N}$. Moreover, geological evidence supports temporally persistent tectonic uplift of the northern TP during the early Miocene (George et al., 2001; Zhang et al., 2015) and the significant uplift of the northern TP since the late Miocene (Li et al., 2014). Because of the uplift of the northern TP, Asian drylands in the higher latitudes have formed at least since the early Miocene and further intensified after the late Miocene. The above results indicate that the uplift of the main and northern TP by the early Miocene likely forced drylands to form in central Asia north of $\sim 40^{\circ} \mathrm{N}$.

Our sensitivity experiments are designed to test mainly the first-order effect of the different factors on central Asian drylands. For example, we do not test our results by considering vegetation and ocean feedbacks (Zhang et al., 2019), the potential vegetation feedbacks may notably affect the regional hydroclimate. Moreover, we focus on the changes in large-scale aridity rather than those in local regions not resolved by the model resolution. This is because the climate model used is capable of depicting the large-scale climatic signal, and the climate in local regions receives increased impacts from local paleogeography, which is not accurately captured by models because of the limited horizontal resolution.

\subsection{Comparisons With Geological Records and Implications}

Environmental changes in central Asia south of $\sim 40^{\circ} \mathrm{N}$ can be detected from geological records located in the northeastern TP. Pollen records from the northeastern TP indicate that steppe-desert vegetation has existed in the Eocene and across the Eocene-Oligocene transition (Barbolini et al., 2020; Bosboom et al., 2014; Hoorn et al., 2012). From the Eocene on, existing geological records indicate a stepwise aridification shown by quan- 
titative precipitation reconstruction through composited pollen records in the Qaidam Basin (Jia et al., 2021) and by palynological and rock magnetic records from 50.2 to 28.2 Ma in the Xining Basin (Fang et al., 2015). Significantly, aridity became more pronounced by the early Miocene caused by the uplift of the northern and northeastern TP (Zhang et al., 2015). The above evidence indicates that central Asian drylands in lower latitudes existed at least from the early Cenozoic and underwent stepwise aridification afterward, which is generally consistent with our simulation (Figure 1, e.g., Xining basin) and previous simulations (Tardif et al., 2020; Zhang et al., 2012).

The environment in central Asia north of $\sim 40^{\circ} \mathrm{N}$ was wet during the early Cenozoic and formed drylands around the early Miocene, as shown in both the records and simulations. Previous paleovegetation studies from the northern Junggar Basin, northern Tian Shan and Zaisan $\left(48^{\circ} \mathrm{N}, 85^{\circ} \mathrm{E}\right)$ show wet conditions with forest or forest-steppe vegetation during the Eocene-Oligocene (Akhmetiev \& Zaporozhets, 2014; Sun et al., 2014; Tang et al., 2011; Tardif et al., 2020). From the Eocene on, existing pollen records and aeolian deposits from the northern Tian Shan and the Junggar Basin indicate stepwise aridification, and the transition from wet to dry conditions likely occurs around the early Miocene (Sun et al., 2010; Tang et al., 2011). Particularly, using a palynological record from the fluviolucustrine Jingou River section from the northern Tian Shan, Tang et al. (2011) demonstrated that xerophilous herbs with Chenopodiaceae-Arte-misia pollen dominance gradually replaced the forest-steppe during 23.8-23.3 Ma and continuously developed until $17.3 \mathrm{Ma}$, indicating that late Oligocene wet conditions existed and shifted to dry conditions afterward. The percentages of herbaceous genera also increased markedly between the late Oligocene and the early Miocene in western China (divided by the modern 500-mm isoline of annual precipitation; Lu et al., 2018). The aeolian deposition initiated in Dingshanyanchi and Tieersihabahe in the northern Junggar Basin at $24 \mathrm{Ma}$ (Sun et al., 2010) and along the southwestern margin of the Taklimakan Desert between 26.7 and 22.6 Ma (Zheng et al., 2015) and in the middle reaches of the Yellow River, such as Qinan, since the early Miocene (Guo et al., 2008) likely reflected the formation of deserts at higher latitudes providing stable dust sources since about the early Miocene. On the whole, this evidence likely supports that drylands move to central Asia north of $\sim 40^{\circ} \mathrm{N}$ since about the early Miocene. In terms of simulation, the dry condition over central Asia south of $\sim 40^{\circ} \mathrm{N}$ and wet condition north of $\sim 40^{\circ} \mathrm{N}$ during the Eocene-Oligocene are clearly captured by our simulation and other late Eocene and early Oligocene simulations (Barbolini et al., 2020; Tardif et al., 2020). Although the comparison of the various proxy records with the modeled central Asian stepwise aridification is affected by local variations and transient climate events, there is broad agreement between them. For example, within central Asia $\left(40^{\circ}-50^{\circ} \mathrm{N}, 70^{\circ}-105^{\circ} \mathrm{E}\right)$, the model results show a gradual increase in the area and intensity of drylands, indicating an aridification trend (Figure 1).

Our simulations suggest a high spatial complexity in hydroclimate evolution in inland Asia during the Cenozoic. In middle Asia west of the Tian Shan, aridity gradually intensifies, accompanied by the retreat of the Paratethys Sea from the Pamir to the Caspian basin. In central Asia north of $\sim 40^{\circ} \mathrm{N}$, hydroclimate shifts from wet to dry conditions, accompanied by the northward uplift of the TP. In central Asia south of $\sim 40^{\circ} \mathrm{N}$, hydroclimate changes from dry conditions to the climate over high elevation.

\section{Summary}

We performed 44 experiments to address the evolved processes and underlying mechanisms of central Asian drylands through the Cenozoic. It is found that the retreated Paratethys Sea and the decreased atmospheric $\mathrm{CO}_{2}$ concentration promote aridification in central Asia, but they only slightly change the latitudinal position of the Asian drylands. By comparison, the uplift of the TP makes central Asian drylands move northward, concentrate in narrow latitudinal bands, and increase in intensity.

\section{Data Availability Statement}

The GPCC precipitation data (Schneider et al., 2011) were provided by the NOAA/OAR/ESRL PSL, Boulder, Colorado, USA, from their Web site at https://psl.noaa.gov/data/gridded/data.gpcc.html. The NCEP_Reanalysis 2 data (Kanamitsu et al., 2002) were provided by the NOAA/OAR/ESRL PSL, Boulder, Colorado, USA, from their Web site at https://psl.noaa.gov/data/gridded/data.ncep.reanalysis2.html. 


\section{Acknowledgments}

We sincerely thank Editor Alessandra Giannini and two anonymous reviewers for their insightful and constructive comments. We also acknowledge the NOAA/ OAR/ESRL PSL for providing the reanalysis and observation data. This study was supported by the National Natural Science Foundation of China (41888101), the Strategic Priority Research Program of the Chinese Academy of Sciences (XDA20070103) and the National Natural Science Foundation of China (42071113 and 41775088).

\section{References}

Akhmetiev, M. A., \& Zaporozhets, N. I. (2014). Paleogene events in central Eurasia: Their role in the flora and vegetation cover evolution, migration of phytochore boundaries, and climate changes. Stratigraphy and Geological Correlation, 22, 312-335. https://doi.org/10.1134/ s0869593814030022

Allen, R., Pereira, L., Raes, D., \& Smith, M. (1998). Crop evapotranspiration-Guidelines for computing crop water requirements (FAO Irrigation and Drainage Paper 56). Rome: FAO.

Barbolini, N., Woutersen, A., Dupont-Nivet, G., Silvestro, D., Tardif, D., Coster, P. M. C., et al. (2020). Cenozoic evolution of the steppe-desert biome in central Asia. Science Advances, 6, eabb8227. https://doi.org/10.1126/sciadv.abb8227

Beerling, D. J., \& Royer, D. L. (2011). Convergent Cenozoic $\mathrm{CO}_{2}$ history. Nature Geoscience, 4, 418-420. https://doi.org/10.1038/ngeo1186

Bentsen, M., Bethke, I., Debernard, J. B., Iversen, T., Kirkevåg, A., Seland, Ø., et al. (2013). The Norwegian Earth system model, NorESM1-MPart 1: Description and basic evaluation of the physical climate. Geoscientific Model Development, 6, 687-720. https://doi.org/10.5194/ gmd-6-687-2013

Bosboom, R. E., Abels, H. A., Hoorn, C., van den Berg, B. C. J., Guo, Z., \& Dupont-Nivet, G. (2014). Aridification in continental Asia after the middle Eocene climatic Optimum (MECO). Earth and Planetary Science Letters, 389, 34-42. https://doi.org/10.1016/j.eps1.2013.12.014

Botsyun, S., Sepulchre, P., Donnadieu, Y., Risi, C., Licht, A., \& Rugenstein, J. K. C. (2019). Revised paleoaltimetry data show low Tibetan Plateau elevation during the Eocene. Science, 363, eaaq1436. https://doi.org/10.1126/science.aaq1436

Caves, J. K., \& Chamberlain, C. P. (2018). The evolution of hydroclimate in Asia over the Cenozoic: A stable-isotope perspective. Earth-Science Reviews, 185, 1129-1156. https://doi.org/10.1016/j.earscirev.2018.09.003

Deng, T., Wang, X., Wu, F., Wang, Y., Li, Q., Wang, S., \& Hou, S. (2019). Review: Implications of vertebrate fossils for paleo-elevations of the Tibetan Plateau. Global and Planetary Change, 174, 58-69. https://doi.org/10.1016/j.gloplacha.2019.01.005

Ding, L., Spicer, R. A., Yang, J., Xu, Q., Cai, F., Li, S., et al. (2017). Quantifying the rise of the Himalaya orogen and implications for the South Asian monsoon. Geology, 45, 215-218. https://doi.org/10.1130/g38583.1

Dowsett, H. J., Robinson, M. M., Haywood, A. M., Salzmann, U., Hill, D., Sohl, L., et al. (2010). The PRISM3D paleoenvironmental reconstruction. Stratigraphy, 7, 123-139.

Dupont-Nivet, G., Krijgsman, W., Langereis, C. G., Abels, H. A., Dai, S., \& Fang, X. M. (2007). Tibetan Plateau aridification linked to global cooling at the Eocene-Oligocene transition. Nature, 445, 635-638. https://doi.org/10.1038/nature05516

Fang, X., Dupont-Nivet, G., Wang, C., Song, C., Meng, Q., Zhang, W., et al. (2020). Revised chronology of central Tibet uplift (Lunpola basin). Science Advances, 6, eaba7298. https://doi.org/10.1126/sciadv.aba7298

Fang, X., Zan, J. B., Appel, E., Lu, Y., Song, C. H., Dai, S., \& Tuo, S. B. (2015). An Eocene-Miocene continuous rock magnetic record from the sediments in the Xining basin, NW China: Indication for Cenozoic persistent drying driven by global cooling and Tibetan Plateau uplift. Geophysical Journal International, 201, 78-89. https://doi.org/10.1093/gji/ggv002

Farnsworth, A., Lunt, D. J., Robinson, S. A., Valdes, P. J., Roberts, W. H. G., Clift, P. D., et al. (2019). Past East Asian monsoon evolution controlled by paleogeography, not $\mathrm{CO}_{2}$. Science Advances, 5, eaax 1697. https://doi.org/10.1126/sciadv.aax 1697

Fu, Q., \& Feng, S. (2014). Responses of terrestrial aridity to global warming. Journal of Geophysical Research: Atmospheres, 119, 7865-7875. https://doi.org/10.1002/2014JD021608

George, A. D., Marshallsea, S. J., Wyrwoll, K.-H., Chen, J., \& Lu, Y. (2001). Miocene cooling in the northern Qilian Shan, northeastern margin of the Tibetan Plateau, revealed by apatite fission-track and vitrinite-reflectance analysis. Geology, 29, 939-942. https://doi. org/10.1130/0091-7613(2001)029<0939:MCITNQ>2.0.CO;2

Goldner, A., Herold, N., \& Huber, M. (2015). Antarctic glaciation caused ocean circulation changes at the Eocene-Oligocene transition. Nature, 519, 378. https://doi.org/10.1038/nature14220

Guo, Z., Sun, B., Zhang, Z. S., Peng, S. Z., Xiao, G. Q., Ge, J. Y., et al. (2008). A major reorganization of Asian climate by the early Miocene. Climate of the Past, 4, 153-174. https://doi.org/10.5194/cp-4-153-2008

Haywood, A. M., Dowsett, H. J., Robinson, M. M., Stoll, D. K., Dolan, A. M., Lunt, D. J., et al. (2011). Pliocene model Intercomparison Project (PlioMIP): Experimental design and boundary conditions (experiment 2). Geoscientific Model Development, 4, 571-577. https://doi. org/10.5194/gmd-4-571-2011

Hoorn, C., Straathof, J., Abels, H. A., Xu, Y. D., Utescher, T., \& Dupont-Nivet, G. (2012). A late Eocene palynological record of climate change and Tibetan Plateau uplift (Xining basin, China). Palaeogeography, Palaeoclimatology, Palaeoecology, 344, 16-38. https://doi.org/10.1016/j. palaeo.2012.05.011

Jia, Y., Wu, H., Zhang, W., Li, Q., Yu, Y., Zhang, C., \& Sun, A. (2021). Quantitative Cenozoic climatic reconstruction and its implications for aridification of the northeastern Tibetan Plateau. Palaeogeography, Palaeoclimatology, Palaeoecology, 567, 110244. https://doi.org/10.1016/j. palaeo.2021.110244

Kanamitsu, M., Ebisuzaki, W., Woollen, J., Yang, S. K., Hnilo, J. J., Fiorino, M., \& Potter, G. L. (2002). NCEP-DOE AMIP-II reanalysis (R-2). Bulletin of the American Meteorological Society, 83, 1631-1643. https://doi.org/10.1175/bams-83-11-1631(2002)083<1631:NAR>2.3.CO;2

Li, J., Fang, X., Song, C., Pan, B., Ma, Y., \& Yan, M. (2014). Late Miocene-Quaternary rapid stepwise uplift of the NE Tibetan Plateau and its effects on climatic and environmental changes. Quaternary Research, 81, 400-423. https://doi.org/10.1016/j.yqres.2014.01.002

Li, J. X., Yue, L. P., Roberts, A. P., Hirt, A. M., Pan, F., Guo, L., et al. (2018). Global cooling and enhanced Eocene Asian mid-latitude interior aridity. Nature Communications, 9, 3026. https://doi.org/10.1038/s41467-018-05415-x

Li, X., Zhang, R., Zhang, Z., \& Yan, Q. (2018). What enhanced the aridity in Eocene Asian inland: Global cooling or early Tibetan Plateau uplift? Palaeogeography, Palaeoclimatology, Palaeoecology, 510, 6-14. https://doi.org/10.1016/j.palaeo.2017.10.029

Licht, A., Dupont-Nivet, G., Pullen, A., Kapp, P., Abels, H. A., Lai, Z., et al. (2016). Resilience of the Asian atmospheric circulation shown by Paleogene dust provenance. Nature Communications, 7, 12390. https://doi.org/10.1038/ncomms12390

Lioubimtseva, E., \& Henebry, G. M. (2009). Climate and environmental change in arid central Asia: Impacts, vulnerability, and adaptations. Journal of Arid Environments, 73, 963-977. https://doi.org/10.1016/j.jaridenv.2009.04.022

Lippert, P. C., van Hinsbergen, D. J. J., \& Dupont-Nivet, G. (2014). Early Cretaceous to present latitude of the central proto-Tibetan plateau: A paleomagnetic synthesis with implications for Cenozoic tectonics, paleogeography, and climate of Asia. In J. Nie, G. Hoke, \& B. Horton (Eds.), Toward an improved understanding of uplift mechanisms and the elevation history of the Tibetan Plateau (pp. 1-21). Boulder, CO: Geological Society of America. https://doi.org/10.1130/2014.2507(01)

Liu, X., Dong, B., Yin, Z. Y., Smith, R. S., \& Guo, Q. (2019). Continental drift, plateau uplift, and the evolutions of monsoon and arid regions in Asia, Africa, and Australia during the Cenozoic. Science China Earth Sciences, 62, 1053-1075. https://doi.org/10.1007/s11430-018-9337-8

Lu, H., Wang, X., Wang, X., Chang, X., Zhang, H., Xu, Z., et al. (2019). Formation and evolution of Gobi desert in central and eastern Asia. Earth-Science Reviews, 194, 251-263. https://doi.org/10.1016/j.earscirev.2019.04.014 
Lu, L., Mao, L.-F., Yang, T., Ye, J.-F., Liu, B., Li, H.-L., et al. (2018). Evolutionary history of the angiosperm flora of China. Nature, 554, 234-238. https://doi.org/10.1038/nature25485

Meijer, N., Dupont-Nivet, G., Abels, H. A., Kaya, M. Y., Licht, A., Xiao, M., et al. (2019). Central Asian moisture modulated by proto-Paratethys Sea incursions since the early Eocene. Earth and Planetary Science Letters, 510, 73-84. https://doi.org/10.1016/j.epsl.2018.12.031

Miao, Y. F., Herrmann, M., Wu, F. L., Yan, X. L., \& Yang, S. L. (2012). What controlled mid-late Miocene long-term aridification in central Asia? - global cooling or Tibetan plateau uplift: A review. Earth-Science Reviews, 112, 155-172. https://doi.org/10.1016/j.earscirev.2012.02.003

Neale, R. B., Richter, J., Park, S., Lauritzen, P. H., Vavrus, S. J., Rasch, P. J., \& Zhang, M. (2013). The mean climate of the Community Atmosphere Model (CAM4) in forced SST and fully coupled experiments. Journal of Climate, 26, 5150-5168. https://doi.org/10.1175/jcli-d-12-00236.1

Paxman, G. J. G., Jamieson, S. S. R., Hochmuth, K., Gohl, K., Bentley, M. J., Leitchenkov, G., \& Ferraccioli, F. (2019). Reconstructions of Antarctic topography since the Eocene-Oligocene boundary. Palaeogeography, Palaeoclimatology, Palaeoecology, 535, 109346. https://doi. org/10.1016/j.palaeo.2019.109346

Quan, C., Liu, Z. H., Utescher, T., Jin, J. H., Shu, J. W., Li, Y. X., \& Liu, Y. S. (2014). Revisiting the Paleogene climate pattern of east Asia: A synthetic review. Earth-Science Reviews, 139, 213-230. https://doi.org/10.1016/j.earscirev.2014.09.005

Ramstein, G., Fluteau, F., Besse, J., \& Joussaume, S. (1997). Effect of orogeny, plate motion and land-sea distribution on Eurasian climate change over the past 30 million years. Nature, 386, 788-795. https://doi.org/10.1038/386788a0

Royden, L. H., Burchfiel, B. C., \& van der Hilst, R. D. (2008). The geological evolution of the Tibetan Plateau. Science, 321, 1054-1058. https:// doi.org/10.1126/science. 1155371

Schneider, U., Becker, A., Finger, P., Meyer-Christoffer, A., Rudolf, B., \& Ziese, M. (2011). GPCC Full data reanalysis version 6.0 at 1.0 $0^{\circ}$ : Monthly land-surface precipitation from rain-Gauges built on GTS-based and historic data. https://doi.org/10.5676/DWD_GPCC/FD_M_V5677_5100

Scotese, C. R. (2001). Digital paleogeographic map archive on CD-ROM (PALEOMAP Project). Arlington, TX: Univ. Texas.

Sha, Y. Y., Shi, Z. G., Liu, X. D., An, Z. S., Li, X. Z., \& Chang, H. (2018). Role of the Tian Shan mountains and Pamir Plateau in increasing spatiotemporal differentiation of precipitation over interior Asia. Journal of Climate, 31, 8141-8162. https://doi.org/10.1175/jcli-d-17-0594.1

Spicer, R. A., Su, T., Valdes, P. J., Farnsworth, A., Wu, F.-X., Shi, G., et al. (2020). Why 'the uplift of the Tibetan Plateau' is a myth? National Science Review, 8 . https://doi.org/10.1093/nsr/nwaa1091

Su, T., Farnsworth, A., Spicer, R. A., Huang, J., Wu, F.-X., Liu, J., et al. (2019). No high Tibetan plateau until the Neogene. Science Advances, 5, eaav2189. https://doi.org/10.1126/sciadv.aav2189

Sun, J., Ni, X. J., Bi, S. D., Wu, W. Y., Ye, J., Meng, J., \& Windley, B. F. (2014). Synchronous turnover of flora, fauna, and climate at the Eocene-Oligocene Boundary in Asia. Scientific Reports, 4, 7463. https://doi.org/10.1038/srep07463

Sun, J., Ye, J., Wu, W. Y., Ni, X. J., Bi, S. D., Zhang, Z. Q., et al. (2010). Late Oligocene-Miocene mid-latitude aridification and wind patterns in the Asian interior. Geology, 38, 515-518. https://doi.org/10.1130/g30776.1

Sun, X., \& Wang, P. (2005). How old is the Asian monsoon system?-Palaeobotanical records from China. Palaeogeography, Palaeoclimatology, Palaeoecology, 222, 181-222. https://doi.org/10.1016/j.palaeo.2005.03.005

Tang, Z. H., Ding, Z. L., White, P. D., Dong, X. X., Ji, J. L., Jiang, H. C., et al. (2011). Late Cenozoic central Asian drying inferred from a palynological record from the northern Tian Shan. Earth and Planetary Science Letters, 302, 439-447. https://doi.org/10.1016/j.epsl.2010.12.042

Tapponnier, P., Xu, Z., Francoise, R., Meyer, B., Arnaud, N., Wittlinger, G., \& Jingsui, Y. (2001). Oblique stepwise rise and growth of the Tibet Plateau. Science, 294, 1671-1677. https://doi.org/10.1126/science.105978

Tardif, D., Fluteau, F., Donnadieu, Y., Hir, G. L., Ladant, J.-B., Sepulchre, P., et al. (2020). The origin of Asian monsoons: A modelling perspective. Climate of the Past, 16, 847-865. https://doi.org/10.5194/cp-16-847-2020

Wang, C. S., Dai, J., Zhao, X., Li, Y., Graham, S. A., He, D., et al. (2014). Outward-growth of the Tibetan plateau during the Cenozoic: A review. Tectonophysics, 621, 1-43. https://doi.org/10.1016/j.tecto.2014.01.036

Wang, X., Carrapa, B., Sun, Y., Dettman, D. L., Chapman, J. B., Caves Rugenstein, J. K., et al. (2020). The role of the westerlies and orography in Asian hydroclimate since the late Oligocene. Geology, 48, 728-732. https://doi.org/10.1130/g47400.1

Zhang, C. X., Xiao, G. Q., Guo, Z. T., Wu, H. B., \& Hao, Q. Z. (2015). Evidence of late early Miocene aridification intensification in the Xining basin caused by the northeastern Tibetan Plateau uplift. Global and Planetary Change, 128, 31-46. https://doi.org/10.1016/j. gloplacha.2015.02.002

Zhang, R., Jiang, D., Ramstein, G., Zhang, Z., Lippert, P. C., \& Yu, E. T. (2018). Changes in Tibetan plateau latitude as an important factor for understanding East Asian climate since the Eocene: A modeling study. Earth and Planetary Science Letters, 484, 295-308. https://doi. org/10.1016/j.eps1.2017.12.034

Zhang, R., Jiang, D., \& Zhang, Z. (2019). Vegetation and ocean feedbacks on the Asian climate response to the uplift of the Tibetan Plateau. Journal of Geophysical Research: Atmospheres, 124, 6327-6341. https://doi.org/10.1029/2019jd030503

Zhang, Z., Flatoy, F., Wang, H. J., Bethke, I., Bentsen, M., \& Guo, Z. T. (2012). Early Eocene Asian climate dominated by desert and steppe with limited monsoons. Journal of Asian Earth Sciences, 44, 24-35. https://doi.org/10.1016/j.jseaes.2011.05.013

Zhang, Z., Ramstein, G., Schuster, M., Li, C., Contoux, C., \& Yan, Q. (2014). Aridification of the Sahara desert caused by Tethys sea shrinkage during the late Miocene. Nature, 513, 401-404. https://doi.org/10.1038/nature13705

Zheng, H. B., Wei, X. C., Tada, R. J., Clift, P. D., Wang, B., Jourdan, F., et al. (2015). Late Oligocene-early Miocene birth of the Taklimakan Desert. Proceedings of the National Academy of Sciences of the United States of America, 112, 7662-7667. https://doi.org/10.1073/ pnas. 1424487112

Zoura, D., Hill, D. J., Dolan, A. M., Hunter, S. J., Tang, Z., \& Haywood, A. M. (2019). Atmospheric carbon dioxide, ice sheet and topographic constraints on palaeo moisture availability in Asia. Earth and Planetary Science Letters, 519, 12-27. https://doi.org/10.1016/j.epsl.2019.04.035 